\title{
New host, geographical records, and factors affecting the prevalence of helminths infection from synanthropic rodents in Yucatán, Mexico
}

\section{J. A. PANTI-MAY ${ }^{1 *}$, E. PALOMO-ARJONA², Y. GURUBEL-GONZÁLEZ2 M. A. TORRES-CASTRO³ , V. M. VIDAL-MARTíNEZ ${ }^{4}$, C. MACHAIN-WILLIAMS ${ }^{5}$, S. F. HERNÁNDEZ-BETANCOURT ${ }^{2}$, M. DEL ROSARIO ROBLES ${ }^{6}$}

\begin{abstract}
${ }^{1 *} \mathrm{PhD}$ in Agricultural Science, Campus of Biological and Agricultural Science, Autonomous University of Yucatán, Mérida, México, E-mail: pantialonso@gmail.com; ${ }^{2}$ Department of Zoology, Campus of Biological and Agricultural Science, Autonomous University of Yucatán, Mérida, México; 'Laboratory of Emerging and Re-emerging Diseases, "Dr. Hideyo Noguchi" Regional Research Center, Autonomous University of Yucatán, Mérida, México; "Laboratory of Aquatic Pathology, Center for Research and Advanced Studies of the National Polytechnic Institute-Mérida Unit, Mérida, México; 'Laboratory of Arbovirology, "Dr. Hideyo Noguchi” Regional

Research Center, Autonomous University of Yucatán, Mérida, México; ${ }^{6} \mathrm{C} e n t e r$ of Parasitological Studies and Vectors, CONICET- National University of La Plata, La Plata, Argentina
\end{abstract}

\section{Article info}

Received January 21, 2017 Accepted April 27, 2017

\section{Summary}

The aim of this paper was to study the occurrence of helminths in Mus musculus and Rattus rattus from urban, suburban and rural settlements in Yucatán, Mexico; and to analyse the host factors (e.g. sex) related to helminths' distribution. Helminths in a total of 279 rodents were surveyed by visual examination of the liver for metacestodes and faecal examination for helminth eggs using the formalin-ethyl acetate sedimentation technique. The cestodes Hydatigera taeniaeformis (metacestodes detected in the liver) and Hymenolepis diminuta , and the nematodes Aspiculuris sp., Nippostrongylus brasiliensis, Syphacia muris, Syphacia obvelata, and Trichuris muris were identified. In M. musculus, the prevalence of infection with $T$. muris and $H$. taeniaeformis was higher in the rural village compared to those in the suburban neighbourhood. For $R$. rattus, a higher prevalence of infection with $H$. diminuta was found in the urban site compared to that in the suburban site. This study reports the occurrence of $H$. diminuta among rodents living in close proximity to humans, representing a potential public health risk. In addition, this survey increases our understanding of dynamic transmission among intestinal helminths recorded in Yucatán, Mexico.

Keywords: Mus musculus; Rattus rattus; helminths; zoonoses; Mexico

\section{Introduction}

Mus musculus Linnaeus 1758 and Rattus rattus Linnaeus 1758 are two of the most important synanthropic rodents in the world (Battersby et al., 2008). These species are the cause of extensive economic damage to stored food, farms, industries, and households (Drummond, 2001). Also, they represent an important health risk due to the zoonotic pathogens they harbour and spread, such as viruses, bacteria, protozoa and helminths (Meerburg et al., 2009).

Synanthropic rodents inhabit non-commensal (e.g., islands, forests) and commensal habitats (e.g., households, farms) (Batters- by et al., 2008). In urban areas, these rodents are usually abundant in low-income neighbourhoods with precarious households and lack of basic services such as garbage disposal, piped water, and electricity (Langton et al., 2001; de Masi et al., 2009). In rural settlements, the presence of extensive areas of ground, vegetation coverage, and livestock, are factors favouring the abundance of synanthropic rodents (Langton et al., 2001; Promkerd et al., 2008). All these factors favour the close contact with inhabitants which could increase the risk for pathogen transmission (Costa et al., 2014).

The helminth fauna of the synanthropic $M$. musculus and $R$. rattus has been studied in both urban and rural areas from several coun-

\footnotetext{
${ }^{*}$ - corresponding author
} 
tries of the world (e.g. de León, 1964, Waugh et al., 2006, Rafique et al., 2009, Mohd Zain et al., 2012, Panti-May et al., 2015). However, in Mexico, few studies have examined the intestinal parasites of synanthropic rodents (Coronel-Guevara, 1953; García-Prieto, 1986; Falcón-Ordaz et al., 2010; García-Prieto et al., 2012; PantiMay et al., 2015), and only one of them has been carried out in an urban area (Tay Zavala et al., 1999). This study reported Hymenolepis diminuta Rudolphi 1819 and Rodentolepis nana Von Siebold 1852 among $R$. rattus and $R$. norvegicus populations.

On other hand, in Mexico, the majority of scientific publications on the helminths in synanthropic rodents have been reported from less than 50 specimens, and without analysing the rodent population characteristics such as sex, age, sexual activity or related to the type of environment therefore limiting the scope of those studies (Tay Zavala et al., 1999; Pulido-Flores et al., 2005; Falcón-Ordaz et al., 2010).

In south-eastern Mexico, only the species Nippostrongylus brasiliensis Travassos 1914, Hydatigera taeniaeformis (larvae) Batsch 1786, Trichuris muris Schrank 1788, and Syphacia muris Yamaguti 1935 have been reported from populations of $M$. musculus and $R$. rattus in a rural community in the state of Yucatán (Panti-May et al., 2015).

The aim of this study was to identify helminths from M. musculus and $R$. rattus trapped in urban, suburban and rural settlements in Yucatán, Mexico; including demographic factors such as sex, age, and maturity in relationship to the distribution of helminths, so that we could determine the potential health risk of zoonotic parasites carried by rodents.

\section{Materials and Methods}

\section{Study sites}

This study was carried out within the residential neighbourhoods of San Jose Tecoh (20 $\left.53^{\prime} 16.0^{\prime \prime} \mathrm{N}, 89^{\circ} 37^{\prime} 19.9^{\prime \prime} \mathrm{W}\right)$ and Plan de Ayala Sur (20 $\left.54^{\prime} 54.0^{\prime \prime} \mathrm{N}, 89^{\circ} 37^{\prime} 22.8^{\prime \prime} \mathrm{W}\right)$ in the city of Mérida, and the village of Opichen ( $\left.20^{\circ} 33^{\prime} 05.26^{\prime \prime} \mathrm{N}, 89^{\circ} 51^{\prime} 21.76^{\prime \prime} \mathrm{W}\right)$, in Yucatán, Mexico. The urban studied site (San Jose Tecoh) is an area of 1,112,984 $\mathrm{m}^{2}$ and $~ 6001$ inhabitants (Instituto Nacional de Estadística y Geografía, 2012). Its infrastructure is characterized by having paved streets, small businesses, several households in poor conditions showing cracks or holes in doors or windows, and a few vegetated areas. In the backyard and premises, it is common to find some weeds, shrubs, and unserviceable domestic appliances. The suburban studied site (Plan de Ayala Sur) is located within the 'Cuxtal' Ecological Reserve, where the vegetation is representative of a low deciduous tropical forest. It is an area of 1,336,707 $\mathrm{m}^{2}$ and has $~ 3037$ inhabitants (Instituto Nacional de Estadística y Geografía, 2012). This neighbourhood is growing and extending the coverage of basic service such as piped water, electricity and paved roads. It is characterized by having many small households in poor conditions, small businesses, vacant lots, farms, and secondary forest patches at the periphery of the neighbourhood. In the majority of the backyards, it is common to find weeds, shrubs, fruit trees, hen houses, unserviceable domestic appliances and construction rubbish. The rural studied site (Opichen) is an area of $1,460,466 \mathrm{~m}^{2}$ and has $~ 4761$ inhabitants (Instituto Nacional de Estadística y Geografía, 2012). It is located at the western part of Yucatán. The majority of inhabitants live in houses constructed with limestone, wooden poles and thatched with palm leaves adjacent to small rooms constructed with concrete blocks, and it is common to find backyard animals such as chickens, pigs, and cattle. Weeds, shrubs, fruit trees, and vegetable patch plots are also commonly present in the yards.

\section{Rodent trapping}

In the neighbourhoods, rodents were trapped from May to October 2013, whereas in the rural village, the trapping was conducted in August and September 2013. Weekly, Sherman traps (two sizes were used, $8 \times 9 \times 23 \mathrm{~cm}$ and $8 \times 9.5 \times 30.5 \mathrm{~cm}$; HB Sherman Traps Inc., Tallahassee, Florida, USA) were set in each household during three consecutive nights (Panti-May et al., 2016). Traps were baited with a mixture of oatmeal and vanilla essence and were distributed inside the house and yard, where signs of rodent activity and potential sources of food or shelter were identified. The rodent trapping was conducted under license from the Mexican Ministry of Environment (SGPA/ DGVS/02528/13).

\section{Ethics}

Trapped rodents were transported to the laboratory, anesthetized with an intraperitoneal injection of sodium pentobarbital, and euthanized by overdose of the same product. Handling of rodents in the field and laboratory, was following the guidelines of the American Society of Mammalogists for the use of wild mammals in research (Sikes et al., 2011), the guidelines of the American Veterinary Medical Association for the euthanasia of animals (Leary et al., 2013), and national specifications for the transportation and euthanasia of animals (Secretaría de Agricultura, Ganadería, Desarrollo Rural, Pesca y Alimentación, 1999).

\section{Parasitological examination}

The faeces of 173 M. musculus and $106 R$. rattus were examined from three sites (see Table 1). Out of $173 \mathrm{M}$. musculus examined, $81(46.8 \%)$ were females and $141(81.5 \%)$ were adults, while 106 $R$. rattus examined, $59(55.7 \%)$ were females and 55 adults $(51.9$ $\%)$. Liver was examined for larval cestodes in fresh. The faecal and caecum contents were examined for helminth eggs using the formalin-ethyl acetate sedimentation technique (World Health Organization, 2012). Briefly, $\sim 1 \mathrm{~g}$ of the content was homogenized in a centrifuge tube containing $10 \mathrm{~mL}$ of $10 \%$ formalin. After homogenization $3 \mathrm{~mL}$ of ethyl acetate were added to the suspension in the tube. The resulting mix was centrifuged at $450 \mathrm{~g}$ for $3 \mathrm{~min}$. Subsequently, the fatty pug was removed and the supernatant discarded. Finally, $\sim 1 \mathrm{~mL}$ of saline solution $(0.9 \%)$ was added to the sediment and three drops were transferred to a glass slide for 


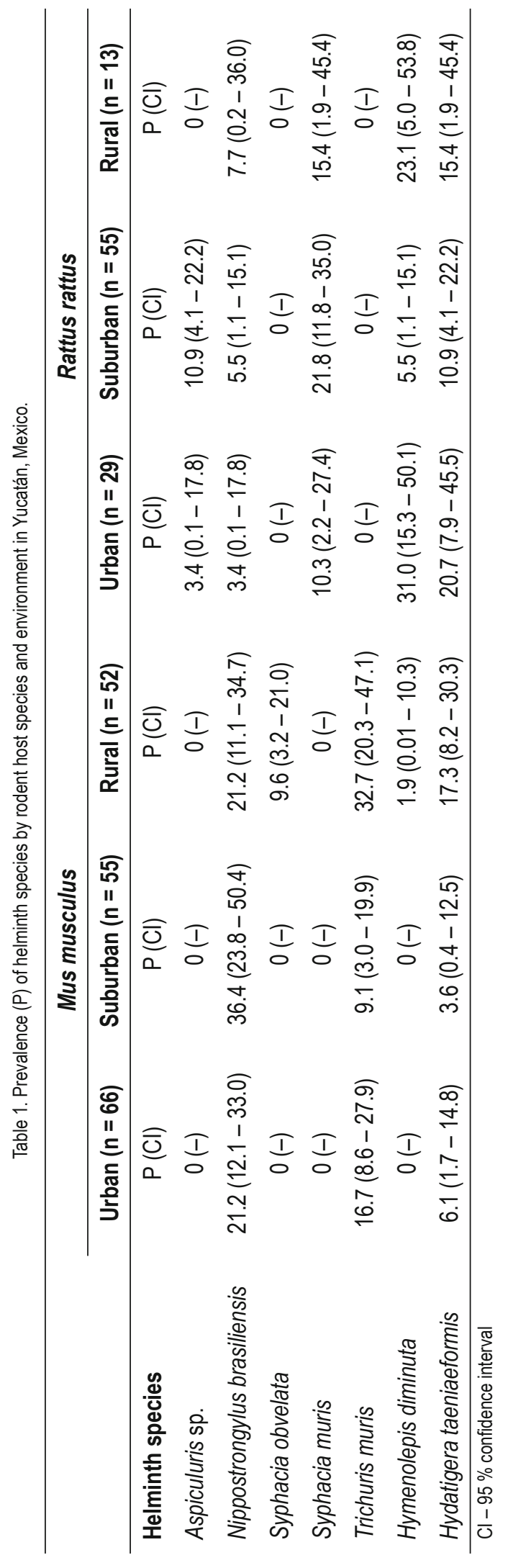


examination. In helminth eggs' positive animals, a subset of adult worms was collected to verify the species of helminths by the use of light microscope.

\section{Data analysis}

Prevalence (percentage of infected animals from faecal o liver examination) was analysed with the software Quantitative Parasitology 3.0 according to Rózsa et al. (2000). The prevalence of helminth infection was compared between mice and rats using the Chi-square test. The relationship between the prevalence of infection of each helminth species relative to demographic characteristics of rodent population, which comprised the host sex, age (mice: subadults $\leq 8 \mathrm{~g}$, adults $>8 \mathrm{~g}$; rats: subadults $\leq 66 \mathrm{~g}$, adults $>66 \mathrm{~g}$ ), maturity (mature: if females were pregnant, lactating or with vagina open, and if males had scrotal testicles; immature, if females were non-pregnant, lactating or with vagina closed, and if males had inguinal/abdominal testicles), and type of environment (urban, suburban or rural) was tested by Chi-squared and Fisher's exact test. These analyses were confined to parasite with an overall prevalence greater than $10 \%$.

\section{Results}

The overall prevalence of intestinal helminths in synanthropic rodents was $42.7 \%$ (119/279). The prevalence of helminth infection was similar between $M$. musculus $(42.8 \%, 74 / 173)$ and $R$. rattus $(42.4 \%, 45 / 106)\left(X^{2}=0.003, \mathrm{df}=1, P=0.96\right)$. Among 74 infected M. musculus, $70.3 \%$ harboured one species of helminth, $25.7 \%$ of specimens had two and $4.0 \%$ of individuals had three different species. Among 45 infected $R$. rattus, $80.0 \%$ harboured one species of helminth, $15.6 \%$ of animals had two and $4.4 \%$ of specimens were infected by three different species.

Seven species of helminths were identified in synanthropic rodents: the cestodes $H$. diminuta and $H$. taeniaeformis larvae; and the nematodes Aspiculuris sp. Schulz 1927, N. brasiliensis, S. muris, Syphacia obvelata Rudolphi 1802, and T. muris. Hymenolepis diminuta, $H$. taeniaeformis, and $N$. brasiliensis were found in both M. musculus and $R$. rattus, while $S$. obvelata and $T$. muris were found exclusively in M. musculus and Aspiculuris sp. and S. muris only in $R$. rattus. In M. musculus, $N$. brasiliensis was the most prevalent helminth (26\%), followed by T. muris (19.1\%). In R. rat-

Table 2. Relationship between prevalence of infection of Mus musculus relative to host sex, age, maturity, and environment from Yucatán, Mexico.

\begin{tabular}{|c|c|c|c|c|}
\hline & \multirow[b]{2}{*}{$\begin{array}{c}\text { No. of mice } \\
\text { examined }\end{array}$} & \multicolumn{3}{|c|}{ Prevalence of helminth species } \\
\hline & & $\begin{array}{c}\text { Nippostrongylus } \\
\text { brasiliensis } \\
\mathrm{n}(\%)\end{array}$ & $\begin{array}{c}\text { Trichuris } \\
\text { muris } \\
\mathrm{n}(\%)\end{array}$ & $\begin{array}{c}\text { Hydatigera } \\
\text { taeniaeformis } \\
\mathrm{n}(\%)\end{array}$ \\
\hline \multicolumn{5}{|l|}{ Sex } \\
\hline Male & 92 & $24(26.1)$ & $17(18.5)$ & $6(6.5)$ \\
\hline \multirow[t]{2}{*}{ Female } & 81 & $21(25.9)$ & $16(19.7)$ & $9(11.1)$ \\
\hline & & $P=1.000$ & $P=0.985$ & $P=0.284$ \\
\hline \multicolumn{5}{|l|}{ Age } \\
\hline Subadult & 15 & $2(13.3)$ & $2(13.3)$ & $1(6.7)$ \\
\hline \multirow[t]{2}{*}{ Adult } & 158 & $43(27.2)$ & $31(19.6)$ & $14(8.9)$ \\
\hline & & $P=0.359$ & $P=0.739$ & $P=1.000$ \\
\hline \multicolumn{5}{|l|}{ Maturity } \\
\hline No & 53 & $10(18.9)$ & $23(19.8)$ & $5(9.7)$ \\
\hline \multirow[t]{2}{*}{ Yes } & 116 & $34(29.3)$ & $10(18.9)$ & $9(7.8)$ \\
\hline & & $P=0.213$ & $P=1.000$ & $P=0.766$ \\
\hline \multicolumn{5}{|l|}{ Site } \\
\hline Urban & 66 & $14(21.2)$ & $11(16.7)$ & $4(6.1)$ \\
\hline Suburban & 55 & $20(36.4)$ & $5(9.1)$ & $2(3.6)$ \\
\hline \multirow[t]{2}{*}{ Rural } & 52 & $11(21.1)$ & $17(32.7)$ & $9(17.3)$ \\
\hline & & $P=0.106$ & $P=0.007$ & $P=0.037$ \\
\hline
\end{tabular}

Chi-square exact significance (two-sided test) or Fisher's exact test where $>25 \%$ of cells have an expected count $<5$ 
Table 3. Relationship between prevalence of infection of Rattus rattus relative to host sex, age, maturity, and environment from Yucatán, Mexico.

\begin{tabular}{|c|c|c|c|c|}
\hline & $\begin{array}{l}\text { No. of rats } \\
\text { examined }\end{array}$ & $\begin{array}{c}\text { Hymenolepis } \\
\text { diminuta } \\
\mathrm{n}(\%)\end{array}$ & $\begin{array}{c}\text { Hydatigera } \\
\text { taeniaeformis } \\
\mathrm{n}(\%)\end{array}$ & $\begin{array}{c}\text { Syphacia } \\
\text { muris } \\
\mathrm{n}(\%)\end{array}$ \\
\hline \multicolumn{5}{|l|}{ Sex } \\
\hline Male & 59 & $9(15.2)$ & $6(10.2)$ & $8(13.6)$ \\
\hline \multirow[t]{2}{*}{ Female } & 47 & $6(12.8)$ & $8(17.0)$ & $9(19.1)$ \\
\hline & & $P=0.932$ & $P=0.455$ & $P=0.608$ \\
\hline \multicolumn{5}{|l|}{ Age } \\
\hline Subadult & 44 & $4(9.1)$ & $5(11.4)$ & $8(18.2)$ \\
\hline \multirow[t]{2}{*}{ Adult } & 62 & $11(17.7)$ & $9(14.5)$ & $9(14.5)$ \\
\hline & & $P=0.329$ & $P=0.856$ & $P=0.812$ \\
\hline \multicolumn{5}{|l|}{ Maturity } \\
\hline No & 32 & $1(3.1)$ & $4(12.5)$ & $6(18.8)$ \\
\hline \multirow[t]{2}{*}{ Yes } & 72 & $13(18.1)$ & $10(13.9)$ & $10(13.9)$ \\
\hline & & $P=0.059$ & $P=1.000$ & $P=0.562$ \\
\hline \multicolumn{5}{|l|}{ Site } \\
\hline Urban & 29 & $9(31.0)$ & $6(20.7)$ & $3(10.3)$ \\
\hline Suburban & 64 & $3(4.7)$ & $6(9.4)$ & $17(26.6)$ \\
\hline \multirow[t]{2}{*}{ Rural } & 13 & $3(23.1)$ & $2(15.4)$ & $2(15.4)$ \\
\hline & & $P=0.001$ & $P=0.283$ & $P=0.166$ \\
\hline
\end{tabular}

tus, S. muris was the most prevalent helminth $(16.0 \%)$, followed by $H$. diminuta (14.2\%). In relation to the trapping site, S. obvelata was found only in the rural site, Aspiculuris sp. in both urban and suburban sites while $N$. brasiliensis, $S$. muris, T. muris, $H$. diminuta and $H$. taeniaeformis were found in the three sites (Table 1).

Mus musculus had higher prevalence $(26.0 \%)$ of infection with $N$. brasiliensis than $R$. rattus $\left(4.7 \% ; X^{2}=18.4, \mathrm{df}=1, P<0.001\right)$, whereas $R$. rattus had higher infection with $H$. diminuta (14.1\%) than $M$. musculus $\left(0.6 \% ; X^{2}=22.4, \mathrm{df}=1, P<0.001\right)$. On the other hand, both rodent species had similar prevalence of $H$. taeniaeformis (M. musculus $8.7 \%, R$. rattus $13.2 \% ; X^{2}=1.0, \mathrm{df}=1$, $P=0.316)$.

The associations of the prevalence of $N$. brasiliensis, $T$. muris, and $H$. taeniaeformis in M. musculus with demographic and environmental variables are shown in the Table 2. The prevalence of $T$. muris was higher in rural rodents $(32.7 \%)$ compared to that from the suburban neighbourhood $\left(9.1 \% ; X^{2}=7.7, \mathrm{df}=1, P=0.005\right)$, but there was no association with the urban site or with demographic variables (sex, age and maturity). The prevalence of infection with $H$. taeniaeformis was higher in the rural site $(17.3 \%)$ compared to the suburban neighbourhood (3.6\%), but no statistical difference was found with that in the urban site or demographic variables. No significant associations were found between $N$. brasiliensis and any of the explanatory variables. For $R$. rattus, the association of prevalence of $H$. diminuta, S. muris and $H$. taeniaeformis with demographic and environmental variables are shown in the Table 3. A higher prevalence of infection with $H$. diminuta was found in the urban site $(31.0 \%)$ compared to the suburban site $(4.7 \%$; Fisher exact test, $P=0.001$ ), but there was no association with the rural site or with the demographic variables (sex, age and maturity). No statistical differences were found between $S$. muris and $H$. taeniaeformis and any of the explanatory variables.

\section{Discussion}

In Mexico, most of the parasitological studies on synanthropic rodents have been conducted in rural environments such as farms or villages (Gutierrez-González, 1980; Pulido-Flores et al., 2005; Falcón-Ordaz et al., 2010; Panti-May et al., 2015). These studies have reported a total of nine species of helminths in both $M$. musculus and $R$. rattus, whereas the only study conducted in an urban settlement reported $H$. diminuta and $R$. nana among $R$. rat- 
Table 4. List of intestinal helminth species recorded in Mus musculus and Rattus rattus from Mexico.

\begin{tabular}{|c|c|c|c|c|}
\hline Helminth species & Host (s) & TE & State & Reference \\
\hline \multicolumn{5}{|l|}{ CESTODA } \\
\hline Monoecocestus sigmodontis & M. musculus and $R$. rattus & $\mathrm{R}$ & Nuevo León & Gutierrez-González 1980 \\
\hline \multirow[t]{2}{*}{ Hymenolepis diminuta } & R. rattus & $U$ & Michoacán & Tay Zavala et al. 1999 \\
\hline & M. musculus and $R$. rattus & USR & Yucatán & Present study \\
\hline \multirow[t]{3}{*}{ Rodentolepis nana } & M. musculus & - & Distrito Federal & García-Prieto 1986 \\
\hline & M. musculus & $\mathrm{R}$ & Hidalgo & Pulido-Flores et al. 2005 \\
\hline & R. rattus & $u$ & Michoacán & Tay Zavala et al. 1999 \\
\hline \multirow[t]{4}{*}{ Hydatigera taeniaeformis larva } & M. musculus & - & Distrito Federal & García-Prieto et al. 2012 \\
\hline & R. rattus & $\mathrm{R}$ & Hidalgo & Pulido-Flores et al. 2005 \\
\hline & M. musculus and $R$. rattus & $\mathrm{R}$ & Yucatán & Panti-May et al. 2015 \\
\hline & M. musculus and $R$. rattus & USR & Yucatán & Present study \\
\hline \multicolumn{5}{|l|}{ ACANTHOCEPHALA } \\
\hline Moniliformis monoliformis & R. rattus & - & Distrito Federal & Coronel-Guevara 1953 \\
\hline \multicolumn{5}{|l|}{ NEMATODA } \\
\hline Gongylonema sp. & R. rattus & $\mathrm{R}$ & Hidalgo & Pulido-Flores et al. 2005 \\
\hline Longistriata sp. & M. musculus and $R$. rattus & - & Nuevo León & Gutierrez-González 1980 \\
\hline Aspiculuris huascaensis & M. musculus & $\mathrm{R}$ & Hidalgo & Falcón-Ordaz et al. 2010 \\
\hline Aspiculuris cf. lahorica & M. musculus & $\mathrm{R}$ & Hidalgo & Pulido-Flores et al. 2005 \\
\hline Aspiculuris sp. & R. rattus & $u$ & Yucatán & Present study \\
\hline \multirow[t]{3}{*}{ Nippostrongylus brasiliensis } & R. rattus & - & Michoacán & Hierro-Huerta 1992 \\
\hline & M. musculus and $R$. rattus & $\mathrm{R}$ & Yucatán & Panti-May et al. 2015 \\
\hline & M. musculus and $R$. rattus & USR & Yucatán & Present study \\
\hline \multirow[t]{3}{*}{ Syphacia muris } & R. rattus & $\mathrm{R}$ & Hidalgo & Pulido-Flores et al. 2005 \\
\hline & R. rattus & $\mathrm{R}$ & Yucatán & Panti-May et al. 2015 \\
\hline & R. rattus & USR & Yucatán & Present study \\
\hline \multirow[t]{2}{*}{ Syphacia obvelata } & M. musculus & $\mathrm{R}$ & Hidalgo & Pulido-Flores et al. 2005 \\
\hline & M. musculus & $\mathrm{R}$ & Yucatán & Present study \\
\hline \multirow[t]{3}{*}{ Trichuris muris } & M. musculus & $\mathrm{R}$ & Hidalgo & Pulido-Flores et al. 2005 \\
\hline & M. musculus & $\mathrm{R}$ & Yucatán & Panti-May et al. 2015 \\
\hline & M. musculus & USR & Yucatán & Present study \\
\hline
\end{tabular}

$\mathrm{U}$, urban; R, rural; USR, urban, suburban, and rural

A dash (-) indicates unavailability of data 
tus populations (Tay Zavala et al., 1999) (Table 4). In this study, seven species of helminths were found in rodents from urban, suburban, and rural environments, $H$. diminuta, $H$. taeniaeformis, Aspiculuris sp., N. brasiliensis, S. muris, S. obvelata, and T. muris. Urban and suburban M. musculus harboured three species of helminths whereas rural M. musculus harboured five species. For $R$. rattus, urban and suburban populations harboured five species of helminths whereas rural rats were infected by four species.

Hymenolepis diminuta, a cestode capable to parasitize rodents, can also infect humans, mainly children living in areas of low socioeconomic status and without adequate sanitation (Tena et al., 1998; Marangi et al., 2003; Martínez-Barbabosa et al., 2012). In this study, $H$. diminuta showed to be more prevalent in $R$. rattus $(14.1 \%)$ than in $M$. musculus $(0.6 \%)$, and has been reported previously as example in Iran (Pakdel et al., 2013), Italy (Milazzo et al., 2010) and Pakistan (Ahmad et al., 2014). Although, this cestode has an indirect life cycle, its presence in trapped rodents inside households indicates its circulation in the studied sites, which could represent a limited health risk by accidental ingestion of insects.

Rodents serve as intermediate hosts for $H$. taeniaeformis and cats act as final hosts (Lavikainen et al., 2016). This study showed a prevalence of infection in M. musculus of $8.7 \%$ and $13.2 \%$ in $R$. rattus. Similar data has been previously reported by Panti-May et al. (2015) in a rural community of Mérida, Yucatán (M. musculus $9.7 \%, R$. rattus $4.3 \%$ ). In the sampled sites for this study, and, in general in Yucatán, the uncontrolled reproduction of stray cats is a serious problem; they forage for food between households laying $H$. taeniaeformis proglottids to the environment. Its occurrence in rodents indicates that it could be enzootic in cat populations in the studied sites, and may thus represent a veterinary interest.

Nippostrongylus brasiliensis and T. muris were the most prevalent nematodes in M. musculus, demonstrating the high adaptation to this parasite to its host. Infection with $N$. brasiliensis occurs mainly through larval penetration of the host' skin by the infective larvae, therefore tolerating high temperatures and humidity, making this parasite very common in synanthropic rodents of the tropical and Caribbean region (de Leon, 1964; Waugh et al., 2006; Panti-May et al., 2015). It has been reported previously in Yucatán, but with higher prevalences in rodents $(M$. musculus $81.2 \%, R$. rattus $43.5 \%$ ) (Panti-May et al., 2015). On the other hand, infection with T. muris occurs through ingestion of embryonated eggs laid in the environment, and therefore the low survival in extreme weather conditions could explain the low prevalence (<20\%) found in this study and in other surveys (see Milazzo et al., 2003; Rafique et al., 2009; Pakdel et al., 2013; Panti-May et al., 2015).

Three oxyuroids were identified, S. muris and Aspiculuris sp. in $R$. rattus and $S$. obvelata in $M$. musculus. Infection with $S$. muris occurs through the ingestion of infective eggs or retrofection (Stahl, 1963), suggesting that the grooming behaviour of rodents could favour its maintenance among rodent populations (Anderson, 2000). The prevalence of $S$. muris in $R$. rattus was similar to that previously reported in Yucatán (17.4\%). By other means, retrofection appears an unlikely mode of transmission for $S$. obvelata (Chan, 1952), which could explain its occurrence only in the rural village(Opichen) with low prevalence. Parasites of the genus Aspiculuris are common in M. musculus, although $R$. rattus is also susceptible to infection. Field studies have shown that these parasites are uncommon in rat populations (de Leon, 1964; Waugh et al., 2006; Rafique et al., 2009; Mohd Zain et al., 2012; Pakdel et al., 2013; Panti-May et al., 2015) but our data indicates that infection may be feasible.

In this study, the prevalence of infection with $N$. brasiliensis was higher in $M$. musculus (26\%) than in $R$. rattus (4.7\%), whereas $R$. rattus had a higher infection with $H$. diminuta $(14.1 \%)$ than $M$. musculus $(0.6 \%)$. The higher prevalence with $N$. brasiliensis in $M$. musculus than in $R$. rattus could be related with the terrestrial habits of $M$. musculus, which can favour a prolonged exposure to larval infective stages of $N$. brasiliensis in the ground, whereas the arboreal habits of $R$. rattus can reduce the contact with larvae (Wells et al., 2007). As intermediate host for $H$. diminuta are arthropods (e.g. beetles), the difference on the prevalence with $H$. diminuta between mice and rats could be related to the feeding behaviour of rodents. Rattus rattus is a selective consumer and prefers to eat more arthropods than M. musculus (Clark, 1982; Riofrío-Lazo \& Páez-Rosas, 2015).

The prevalence of infection and the occurrence of some helminths varied between environments. The prevalence of $T$. muris and $H$. taeniaeformis was higher in rural M. musculus compared with the suburban population, and $S$. obvelata occurred only in the rural site. In addition, urban $R$. rattus had a higher prevalence of infection with $H$. diminuta compared with suburban rats. This shows that climatic and micro-environmental conditions prevalent in the rural site (e.g. ground, vegetation) could favour the viability of infective eggs. In addition, in the case of parasite with direct life cycle, host density can affect the contact rate with infective stages (Arneberg, 2001). For parasites with indirect life cycle (i.e. $H$. taeniaeformis and $H$. diminuta), the dispersion increases with the probability of intermediate host being captured by a suitable predator which reduce the time of exposure of larval stages to the adversity of the external environment (Choisy et al., 2003). This suggests that, the suitability and availability of intermediate hosts also varied between environments.

The results indicate that micro-environmental factors prevalent in each site could alter the dynamic of transmission of helminths present in rodents from the diverse studied sites. To our knowledge, this study is the first to report the presence of $H$. diminuta in M. musculus and the infection with Aspiculuris sp. in $R$. rattus from Mexico. Although this study increases the total number of helminth species known in synanthropic rodents from Yucatán to seven, the number of species is still lower than that reported in other regions in Mexico and Latin America (de Leon, 1964; Pulido-Flores et al., 2005; Waugh et al., 2006). In addition, we report the occurrence of $H$. diminuta among rodent populations foraging in close proximity 
to humans, indicating a limited public health risk, especially to the most vulnerable such as children, the elderly and the immunocompromised. The results present here increase our understanding of the dynamic transmission of intestinal helminths observed in Yucatán, Mexico.

\section{Acknowledgements}

We would like to thank the families from San Jose Tecoh, Plan de Ayala Sur and Opichen for their participation and cooperation in this research. We are also grateful to Lorenzo Sodá and Josue Meza for their support in the field work.

\section{Financial support}

This work was funded by Consejo Nacional de Ciencia y Tecnología (grants 2014-247005, 2008-108929. J.A. Panti-May was supported by a doctoral grant from Consejo Nacional de Ciencia y Tecnología (grant 259164).

\section{References}

Ahmad, M.S., Maqbool, A., Anjum, A.A., Ahmad, N., Khan, M.R., SulTANA, R., Alı, M.A. (2014): Occurance of Hymenolepis diminuta in rats and mice captured from urban localities of Lahore, Pakistan. J. Anim. Plant Sci., 24: $392-396$

ANDERSON, R.C. (2000): Nematode parasites of vertebrates: Their development and tranmission. $2^{\text {nd }}$ Edition, Wallingford, UK, CAB International, $650 \mathrm{pp}$.

Arneberg, P. (2001): An ecological law and its macroecological consequences as revealed by studies of relationships between host densities and parasite prevalence. Ecography, 24: 352 - 358. DOI: 10.1111/j.1600-0587.2001.tb00208.x

Battersby, S., Hirschrorn, R.B., Amman, B.R. (2008): Commensal rodents. In: Bonnefoy, X., Kampen, H., Sweeney, K. (Eds), Public Health Significance of Urban Pests. Copenhagen, Denmark: World Health Organization, pp. $387-419$

Chan, K.F. (1952): Life cycle studies on the nematode Syphacia obvelata. Am. J. Hyg., 56: $14-21$

Cholsy, M., Brown, S.P., Lafferty, K.D., Thomas, F. (2003): Evolution of trophic transmission in parasites: Why add intermediate hosts? Am. Nat., 162: 172 - 181. DOI: 10.1086/375681

CLARK, D.A. (1982): Foraging behavior of a vertebrate omnivore (Rattus rattus): Meal structure, sampling, and diet breadth. Ecology, 63: 763 - 772. DOI: 10.2307/1936797

Coronel-Guevara, M. (1953): Observaciones sobre el ciclo biológico de Moniliformis moniliformis (Bremser, 1811). [Observations on the life cycle of Moniliformis moniliformis (Bremser, 1811)]. B.S. thesis, Mexico City, Mexico: Instituto Politécnico Nacional (In Spanish) Costa, F., Ribeiro, G.S., Felzemburgh, R.D.M., Santos, N., Reis, R.B., Santos, A.C., Fraga, D.B.M., Araujo, W.N., Santana, C., CHILDS, J.E., ET AL. (2014): Influence of household rat infestation on Leptospira transmission in the urban slum environment. PLoS Negl. Trop. Dis., 8: e3338. DOI: 10.1371/journal.pntd.0003338 DE LEON, D.D. (1964): Helminth parasites of rats in San Juan, Puerto Rico. J. Parasitol., 50: 478. DOI: $10.2307 / 3275862$

DE MASI, E., VILAÇA, P.,RazzolINI, M.T.P. (2009): Environmental conditions and rodent infestation in Campo Limpo district, Sao Paulo municipality, Brazil. Int. J. Environ. Health Res., 19: 1 - 16. DOI: 10.1080/09603120802126670

Drummond, D.C. (2001): Rodents and biodeterioration. Int. Biodeterior. Biodegradation, 48: 105 - 111. DOI: 10.1016/S09648305(01)00073-7

Falcón-Ordaz, J., Pulido-Flores, G., Monks, S. (2010): New species of Aspiculuris (Nematoda: Heteroxynematidae), parasite of Mus musculus (Rodentia: Muridae), from Hidalgo, Mexico. Rev. Mex. Biodivers., 81: 669 - 676

García-Prieto, L. (1986): (Estudio taxonómico de algunos céstodos de vertebrados de México). [Taxonomic study of some cestodes in Mexican vertebrates]. B.S. thesis, Mexico City, Mexico: Universidad Nacional Autónoma de México (In Spanish)

García-Prieto, L., Falcón-Ordaz, J., Guzmán-Cornejo, C. (2012): Helminth parasites of wild Mexican mammals: List of species, hosts and geographical distribution. Zootaxa, 92: 1 - 92.

GUTIERREZ-GonZÁlEZ, J. (1980): (Algunos helmintos parásitos en ratas silvestres de Apodaca, Nuevo León, México). [Some helminth parasites in wild rats from Apodaca, Nuevo Leon, Mexico]. B.S. thesis, Nuevo León, México: Universidad Autónoma de Nuevo León (In Spanish)

Hierro-Huerta, P. (1992): (Helmintofauna de la "rata de alcantarilla" Rattus norvegicus Erxleben, 1777, de la Ciudad de Morelia, Michoacán, México). [Helminthfauna of the sewer rat Rattus norvegicus Erxleben, 1777, from the city of Morelia, Michoacan, Mexico]. B.S. thesis, Michoacán, México: Universidad Michoacana de San Nicolás de Hidalgo (In Spanish)

Instituto Nacional de Estadística y Geografía (2012): Inventario nacional de viviendas. [National inventory of households]. Retrieved May 25, 2013 from http://www3.inegi.org.mx/sistemas/mapa/inv/ Default.aspx?bi=1 (In Spanish)

Langton, S.D., Cowan, D.P., Meyer, A.N. (2001): The occurrence of commensal rodents in dwellings as revealed by the 1996 English House Condition Survey. J. Appl. Ecol., 38: 699 - 709. DOI: 10.1046/j.1365-2664.2001.00631.x

LaVikainen, A., Iwaki, T., Haukisalmi, V., Konyaev, S. V., Casiraghi, M., Dokuchaev, N.E., Galimberti, A., Halajian, A., Henttonen, H., IChikaWA-SEKI, M., ET AL. (2016): Reappraisal of Hydatigera taeniaeformis (Batsch, 1786) (Cestoda: Taeniidae) sensu lato with description of Hydatigera kamiyai n. sp. Int. J. Parasitol., 46: 361 - 374. DOI: 10.1016/j.jpara.2016.01.009

Leary, S., Underwood, W., Lilly, E., Anthony, R., Cartner, S., Corey, D., Grandin, T., Greenacre, C., Collins, F., Greenacre, C., et AL. (2013): AVMA guidelines for the euthanasia of animals: 2013 Edition. Illinois, USA, American Veterinary Medical Association, $102 \mathrm{pp}$. 
Marangl, M., Zechinl, B., Fileti, A., Quaranta, G., Aceti, A. (2003): Hymenolepis diminuta infection in a child living in the urban area of Rome, Italy. J. Clin. Microbiol., 41: 3994 - 3995. DOI: 10.1128/ JCM.41.8.3994

Martínez-Barbabosa, I., Gutiérrez-Cárdenas, M.E., Aguilar-Venegas, J.M., Shea, M., Gutiérrez-Quiroz, M., Ruíz-GonzÁlez, L.A. (2012): Infección por Hymenolepis diminuta en una estudiante universitaria. [Investigation of Hymenolepis diminuta infection in a collage student]. Rev. Biomédica, 23: 61 - 64 (In Spanish)

Meerburg, B.G., Singleton, G.R., KiJlstra, A. (2009): Rodent-borne diseases and their risks for public health. Crit. Rev. Microbiol., 35 : 221 - 270. DOI: 10.1080/10408410902989837

Milazzo, C., de Bellocq, J.G., Cagnin, M., Casanova, J.C., di Bella, C., Feliu, C., Fons, R., Morand, S., Santalla, F. (2003): Helminths and Ectoparasites of Rattus rattus and Mus musculus from Sicily, Italy. Comp. Parasitol., 70: 199 - 204. DOI: 10.1654/4109.1

Milazzo, C., Cagnin, M., Di Bella, C., Geraci, F., Ribas, A. (2010): Helminth fauna of commensal rodents, Mus musculus (Linnaeus, 1758) and Rattus rattus (Linnaeus, 1758) (Rodentia, Muridae) in Sicily (Italy). Rev. Ibero-Latinoamericana Parasitol., 69: 194 - 198 Mohd Zain, S.N., BehNKe, J.M., LewIS, J.W. (2012): Helminth communities from two urban rat populations in Kuala Lumpur, Malaysia. Parasit. Vectors, 5: 47. DOI: 10.1186/1756-3305-5-47

Pakdel, N., Naem, S., Rezael, F., Chalehchaleh, A.A. (2013): A survey on helminthic infection in mice (Mus musculus) and rats (Rattus norvegicus and Rattus rattus) in Kermanshah, Iran. Vet. Res. Forum, 4: 105 - 109

Panti-May, J.A., Hernández-Betancourt, S.F., Rodríguez-VIVAS, R.I., RoBlEs, M.R. (2015): Infection levels of intestinal helminths in two commensal rodent species from rural households in Yucatan, Mexico. J. Helminthol., 89: 42 - 48. DOI: 10.1017/ S0022149X13000576

Panti-May, J.A., Hernández-Betancourt, S.F., Torres-Castro, M.A., Machaín-Williams, C., Cigarroa-Toledo, N., SodÁ, L., López-Manzanero, G., Meza-Sulú, J.R., Vidal-Martínez, V.M. (2016): Population characteristics of human-commensal rodents present in households from Mérida, Yucatán, México. Manter J. Parasite Biodivers., Occas paper 6: 1 - 6

Promkerd, P., Khoprasert, Y., Virathavone, P., Thoummabouth, M., SIRISAK, O., JÄKEL, T. (2008): Factors explaining the abundance of rodents in the city of Luang Prabang, Lao PDR, as revealed by field and household surveys. Integr. Zool., 3: 11 - 20. DOI: 10.1111/j.1749-4877.2008.00069.x

Pulido-Flores, G., Moreno-Flores, S., Monks, S. (2005): Helminths of rodents (Rodentia: Muridae) from Metztitlán, San Crsito- bal, and Rancho Santa Elena, Hidalgo, Mexico. Comp. Parasitol., 72: 186 - 192. DOI: http://dx.doi.org/10.1654/4146

Rafique, A., Rana, S.A., Khan, H.A., Sohall, A. (2009): Prevalence of some helminths in rodents captured from different city structures including poultry farms and human population of Faisalabad, Pakistan. Pak. Vet. J., 29: 141 - 144

Riofrío-Lazo, M., Páez-Rosas, D. (2015): Feeding habits of introduced black rats, Rattus rattus, in nesting colonies of Galapagos petrel on San Cristóbal Island, Galapagos. PLoS One, 10: e0127901. DOI: 10.1371/journal.pone.0127901

Rózsa, L., Reiczigel, J., Majoros, G. (2000): Quantifying parasites in samples of hosts. J. Parasitol., 86: 228 - 232. DOI: 10.1645/0022-3395(2000)086[0228:QPISOH]2.0.CO;2

Secretaría de Agricultura, Ganadería, Desarrollo Rural, Pesca y ALIMENTACIÓN (1999): Especificaciones técnicas para la producción, cuidado y uso de los animales de laboratorio. [Technical specifications for the production, care, and use of laboratory animals]. NOM-062-ZOO-1999. Diario Ofical de la Federación (In Spanish) Sikes, R.S., Gannon, W.L., Animal Care and Use Committee of the American SoCIETY of MammalogISTs (2011): Guidelines of the American Society of Mammalogists for the use of wild mammals in research. J. Mammal., 92: 235 - 253. DOI: 10.1644/10-MAMM-F-355.1

StaHL, W. (1963): Studies on the life cycle of Syphacia muris, the rat pinworm. Keio J. Med., 12: 55 - 60

Tay Zavala, J., Alvarez, T., Gutiérrez Quiroz, M., Sánchez Vega, J., FenÁndez Presas, A. (1999): Zoonosis por helmintos en mamíferos de Morelia, Michoacán, República Mexicana. [Zoonoses by helminths in mammals from Morelia, Michoacan, Mexico]. Rev. Fac. Med. UNAM, 42: 64 - 65 (In Spanish)

Tena, D., Pérez Simón, M., Gimeno, C., Pérez Pomata, M.T., Illescas, S., Amondarain, I., González, A., Domínguez, J., Bisquert, J. (1998): Human infection with Hymenolepis diminuta: case report from Spain. J. Clin. Microbiol., 36: 2375 - 2376

Waugh, C.A., Lindo, J.F., Foronda, P., Angeles-Santana, M., Lorenzo-Morales, J., Robinson, R.D. (2006): Population distribution and zoonotic potential of gastrointestinal helminths of wild rats Rattus rattus and $R$. norvegicus from Jamaica. J. Parasitol., 92: 1014 1018. DOI: $10.1645 / G E-795 R 1.1$

Wells, K., Smales, L.R., Kalko, E.K. V., Pfeiffer, M. (2007): Impact of rain-forest logging on helminth assemblages in small mammals (Muridae, Tupaiidae) from Borneo. J. Trop. Ecol., 23: 35 - 43. DOI: 10.1017/S0266467406003804

World Health Organization (2012): Bench aids for the diagnosis of intestinal parasites. 4th Edition, Geneva, Switzerland, World Health Organization, $20 \mathrm{pp}$. 